\title{
Experimental investigation on the use of steel-concrete bond tests for estimating axial compressive strength of concrete. Part 2: APULOT
}

\section{Investigação experimental sobre o uso de ensaios de aderência aço-concreto para estimativa da resistência à compressão axial do concreto. Parte 2: APULOT}
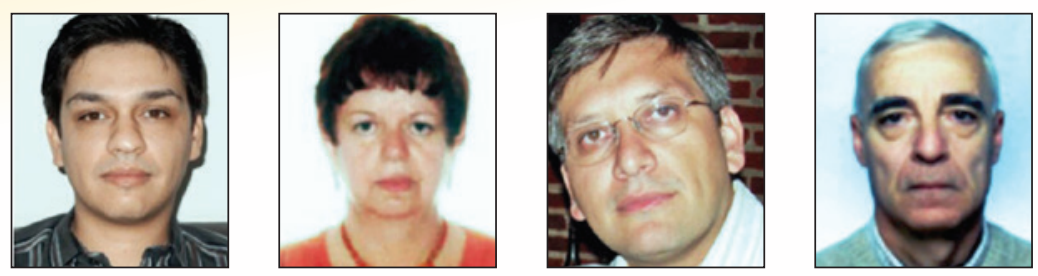

B. V. SILVA

dovalesilva@hotmail.com

M. P. BARBOSA

mbarbosa@dec.feis.unesp.br

L. C. P. SILVA FILHO a Icarlos66@gmail.com

M. S. LORRAIN michel.lorrain@insa-toulouse.fr

\begin{abstract}
The scope of this research investigates the feasibility to use steel-concrete bond tests for estimating the compressive strength of concrete to supplementary use it in the quality control of reinforced concrete. Lorrain and Barbosa (2008)[1] and Lorrain et al. (2011)[2] justify the use of a modified bond test, called APULOT, to estimate the compressive strength of concrete, thereby increasing the possibilities for the technological control of reinforced concrete at construction sites. They propose an adaptation of the traditional pull-out test (POT) method, standardized by CEB/ FIP RC6:1983[3], as this is a low complexity test with the advantage of reduced costs. The use of the APULOT test as a technological control test of concrete at construction sites requires determining a standard and also adapting it from the experimental laboratory practice to the field. The first part of this work evaluated the potential to perform compressive strength estimates from the bond strength data obtained by the POT test. The second part of this paper will present and discuss the test results achieved by the APULOT method. Two concrete compositions of different classes (25 MPa and $45 \mathrm{MPa}$ ) were tested at 3, 7 and 28 days. Ribbed bar specimens (nominal diameters of 8,10 and $12.5 \mathrm{~mm}$ ) were also used in the preparation stage of the specimens, totaling 144 APULOT tests. The results show that under standard test conditions, the correlation between the maximum bond strength and the compressive strength of concrete is satisfactory at all ages tested, corroborating the objective of consolidating this test as a complementary alternative for controlling the quality of reinforced concrete.
\end{abstract}

Keywords: bond steel-concrete; pull-out; APULOT; compressive strength of concrete.

\section{Resumo}

EA presente pesquisa se propõe a estudar a viabilidade do uso de ensaios de aderência aço-concreto para estimativa da resistência à compressão axial do concreto, com o objetivo de empregá-los como um complemento no controle de qualidade do concreto armado. Lorrain e Barbosa (2008) [1]e Lorrain et al. (2011)[2]justificam a utilização de um ensaio de aderência modificado, denominado APULOT, para estimar a resistência à compressão do concreto, incrementando as possibilidades de controle tecnológico do concreto armado em canteiros de obras. Os mesmos propõem uma adaptação do método pull-out test (POT) tradicional, normalizado pela CEB/FIP RC6:1983[3], por ser este um ensaio de baixa complexidade e de custo reduzido. Para viabilizar o uso do ensaio APULOT como ensaio de controle tecnológico do concreto em canteiro de obras é necessário definir um padrão para o mesmo e adaptá-lo da prática experimental do laboratório para o campo. A primeira parte deste trabalho buscou avaliar a potencialidade de efetuar estimativas da resistência à compressão a partir dos dados da tensão de aderência obtidos com uso do POT. Na segunda parte deste trabalho serão apresentados e discutidos resultados de ensaios realizados com o método APULOT. Foram ensaiadas 2 composições de concreto de classes distintas (25 MPa e $45 \mathrm{MPa}$ ), aos 3, 7 e 28 dias. Foram, ainda, usadas na confecção dos corpos de prova barras nervuradas com diâmetros nominais de 8, 10 e 12,5 mm, totalizando 144 ensaios do tipo APULOT. Os resultados obtidos mostram que, sob condições padronizadas de ensaio, a correlação entre a tensão máxima de aderência e a resistência à compressão do concreto é satisfatória, em todas as idades ensaiadas, fortalecendo o propósito de consolidar este ensaio como uma alternativa complementar para controle de qualidade do concreto armado.

Palavras-chave: aderência aço-concreto; pull-out; APULOT; resistência à compressão do concreto.

Univesidade Federal do Rio Grande do Sul, Programa de Pós Graduação em Engenharia Civil, Porto Alegre, RS, Brasil;

Univesidade Estadual Paulista, Departamento de Engenharia Civil, Ilha Solteira, SP, Brasil;

Institut National des Sciences Apliquées, Département de Génie Civil, Toulouse, França. 


\section{Introduction}

This study was conducted at UNESP/SP and is inserted in the APULOT research group composed of researchers from France, Brazil and other countries, which has been working on the improvement of a new test method based on the steel-concrete bond test: the pull-out test (POT), originally proposed as a recommendation from CEB/FIP RC6:1983[3], which is characterized by its simplicity and low cost. In continuity to Part 1 of this article presented in Vale Silva et. al (2013)[4], which addressed standardized POT tests and its perspectives in determining the compressive strength of concrete, the objective of this second part is to analyze the results of another series of tests performed by the authors, which addressed the proposal of the APULOT method, however using PET bottle molds as sample specimens, thus demonstrating that the tests can be performed in a simple manner, not entailing major technological devices. The same concrete compositions, test ages and types of reinforcement bars presented in part 1 of this article [4] were used, however the anchorage length calculation was based on the new premise developed by Lorrain and Barbosa (2008) [1]

\section{Considerations of the APULOT methodology}

The essential characteristic of the APULOT method (Appropriate Pull-Out Test) is the possibility to use it at construction sites in a suitable pull-out type steel-concrete bond test in order to estimate the compressive strength of concrete, thereby obtaining a complement for the technological control of concrete from a bond test. There are numerous bond test configurations found in the literature, as illustrated in Figure 1: (a) Direct "pull-out test" (POT), (b) Eccentric pull-out test, (c) Direct "push-in test" (PIT), (d) Modified pull-out test to minimize the effects of compression, (e) Direct Tensile test, (f) Direct Tensile Test with 3 bars, (g) Extreme Beam End Test, (h) Bending tests in modified beam (beam best), (i) Bending beam test to study anchoring effects, coatings and transfer reinforcement.

According to ACI 408R:2003[6] the test that best reproduces the behavior of steel-concrete bond is the bending test in modified beams (beam-test) (Figure 1(h)). But the most used, due to its simplicity, is the direct pull-out test [3] (Figure 1(a)). Although the pull-out test did not reproduce the bending effects on the steel-concrete bond, resulting in restrictions when the effective bond strength of structural components must be determined, it is interesting for the technological control of concrete, because the pull-out is effective for comparing concretes with different strengths in relation to the bond strength of steel-concrete. Lorrain and Barbosa (2008)[1], aware of this important pull-out feature and to demonstrate that the bond tests could be performed in a simple manner at the construction site, proposed the new APULOT method, using discarded PET bottles as mold specimens and a leaking hydraulic jack piston for the pull-out tests, thus demonstrating this is an easy to implement method and with the advantage of low costs.

The various research details of the APULOT tests are under investigation by the research group designated as the APULOT Group, consisting of various research centers of Excellence ${ }^{1}$. The group believes that by implementing this type of bond test, complementary or as an

\section{Figure 1 - Schematic drawings of some steel-concrete bond tests found in the literature (ALVAREZ, 1998)(5)}

(a) Pull-out (b) Pull-out Eccentric
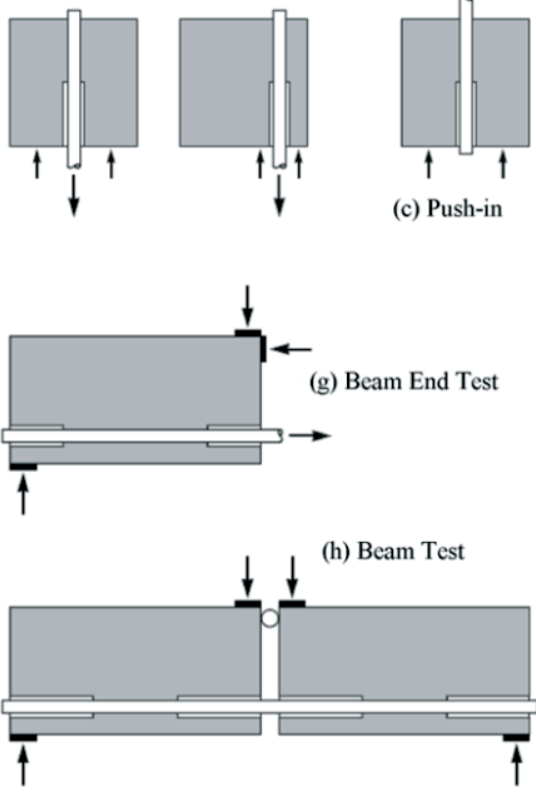

(d) Modified pull-out test to minimize the effects of compression
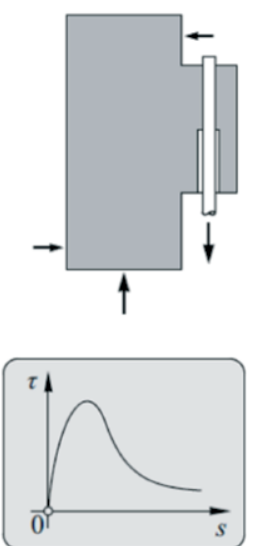

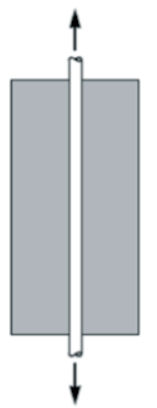

(e) Direct Tensile Test

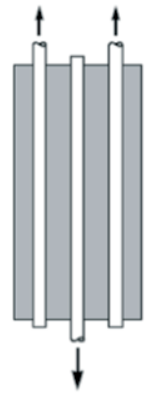

(f) Direct Tensile Test with 3 bars

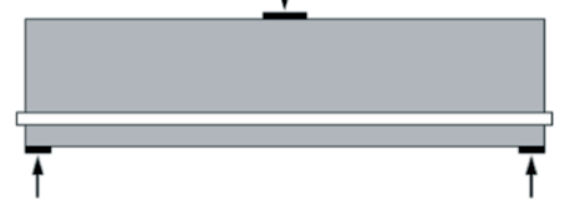


Figure 2 - Simplified flowchart of the APULOT methodology

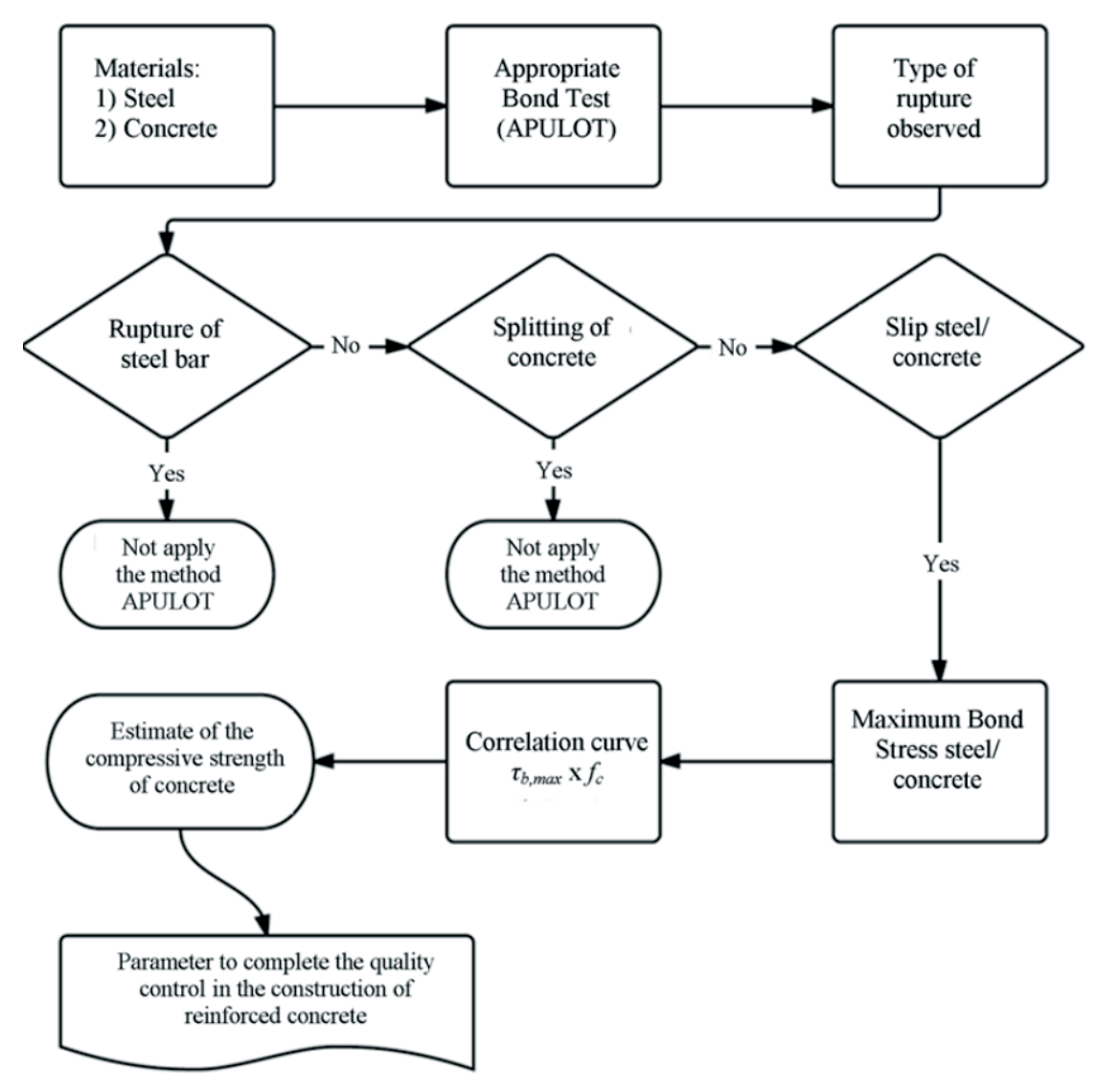

alternative to compression tests traditionally used in civil construction, it could lead to significant improvements in the quality control of construction works, enabling to perform the quality control of concrete at shorter ages, quickly and safely at the construction site itself. Within this objective, there are studies that seek to determine the influence of several variables on the response of bond tests in order to consolidate a test method, for example: evaluation of the influence of surface corrosion on bond [7]; analysis of the procedure to remove the bar from the concrete (pull-out or push-in) [8]; comparison between different geometrical configurations of steel bars on the test response [9], [10]; evaluation of the effect of changes in the concrete cover around the steel bar [11], [12]; analysis of the bond test results using artificial neural networks [13]; evaluation of the mechanical strength influence of the concrete on the bond tests [14], [15]; evaluation of the molds geometry influence on the bond test [16]; Among the studies, besides the experimental activities, there are also numerical simulations [17], [18], which propose to parameterize simpler ways to implement the test at construction sites; and finally the Research Group LEME/UFRGS has been testing the push-in instead of the pull-out system and the parameters for the standardization of the method at construction sites.

It is important that for a satisfactory bond test response, the steel bar slip relative to the concrete must occur, excluding from the correlation curve the results where the steel bar rupture or concrete splitting occurs. Figure 2 illustrates a flowchart for the proper application of the APULOT methodology.

\section{Experimental development}

The characteristics of the materials used in the experimental program and the procedures employed in the bond tests were presented in part 1 [3] of this article. The procedures of the APULOT method

Figure 3 - Dimensions of the specimen for the APULOT test with anchorage length of $10 \varnothing$ (19)

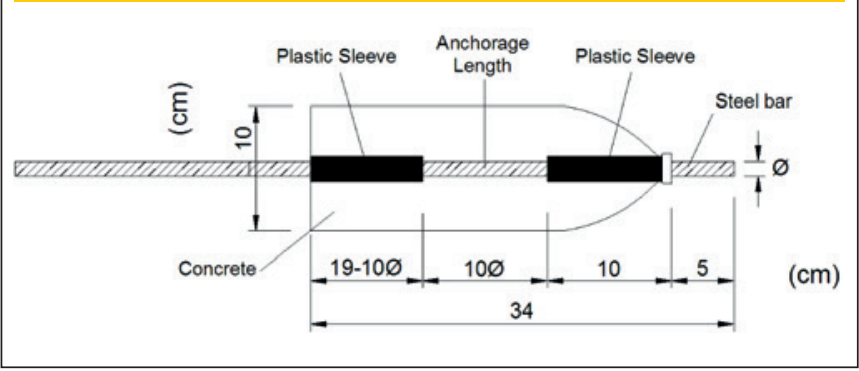




\section{Figure 4 - (a) PET bottle mold (b) Concreting of the PET bottle mold on the metal support}
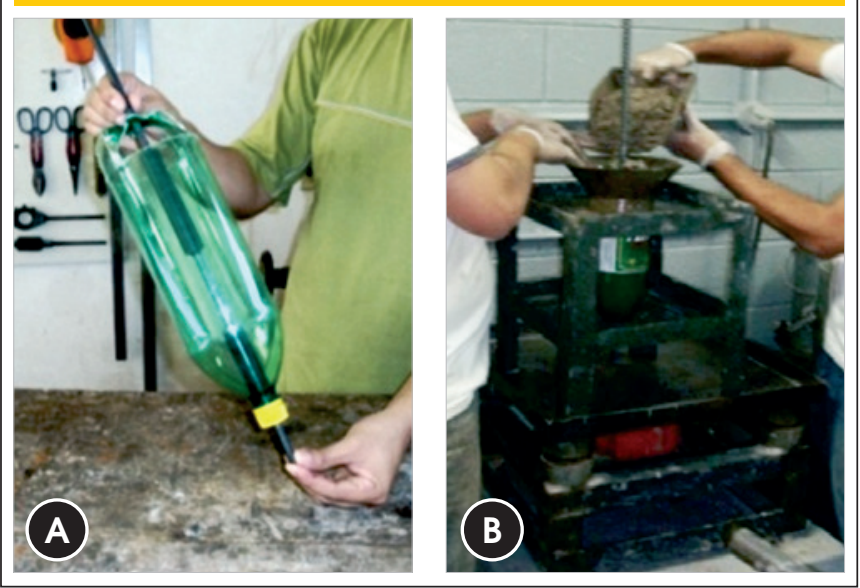

with PET bottle molds will be discussed in part 2 of the article.

Figure 3 illustrates the dimensions of the specimens for the APULOT test method with anchorage length of $10 \varnothing$. The PET bottle molds used as test specimens were prepared as illustrated in Figure 4(a) and positioned on the support for their concreting, as illustrated in Figure 4(b). After $24 \mathrm{~h}$, the test specimens were placed in a temperature and humidity controlled chamber until the failure dates ( 3 days, 7 days and 28 days), note that for a later application of the method at the construction site, the curing procedure in a saturated solution can be used as it is usually employed in the field. Another aspect of the method is that the plastic casing of the PET bottle used as a mold is not removed during curing and is kept there until the end of the pull-out test.

For the first estimate of the experimental anchorage length $\left(l_{\text {exp }}\right)$ of this test, the basic premise used was that the steel bar slip occurs in relation to the surrounding concrete. To satisfy this condition, the bond stress should not cause concrete splitting and the steel stress should not reach the breaking point. Therefore, we used the maximum bond stress values $\left(\tau_{b, \max }\right)$ obtained experimentally in the tests in which slip occurred, [1] and [2]. Thus, through the correlation between the com-

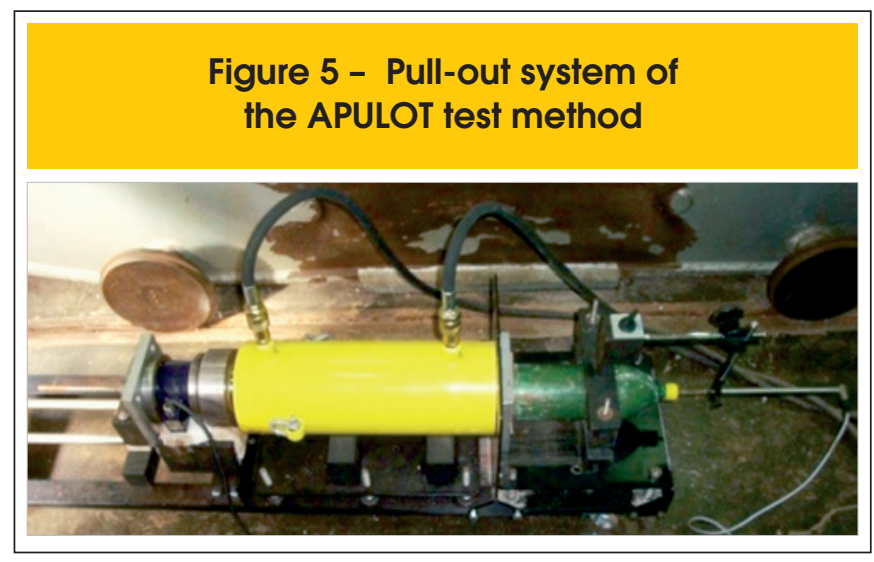

pression strength and maximum bond stress, together with the application of Equation 1, an experimental anchorage length of $10 \varnothing$ was set, where $\varnothing$ is the diameter of the steel bar for the concrete of class 25 $\mathrm{MPa}$ (T25) and the value of $6 \varnothing$ for the concrete of class $45 \mathrm{MPa}$ (T45).

$l_{\text {exp }}=\frac{f_{s y_{.} .}}{4 . \tau_{\mathrm{b}, \text { máx }}}-\cdots$

In Equation 1: $f s y$ is the yield stress of the steel; $\varnothing$ is the diameter of the steel bar; $I_{\text {exp }}$ is the length of the experimental anchorage of the test specimens; $\tau_{b, \max }$ is the maximum bond stress obtained from the correlation curve proposed by Lorrain and Barbosa (2008)[1]. It should be noted that the values used for the anchorage length in this experimental research are part of the first attempts to define this parameter in the APULOT method, which can be reformulated in accordance with the research advances. Another change introduced, compared to the pull-out recommended by RILEM, is that the steel bar has two non-bond areas positioned at the ends of the test specimen, in order to ensure a more uniform bond distribution over the anchorage length. The pull-out system used was the same used in the POT tests and previously described in the previous article: part 1 [4], as illustrated in Figure 5 and the schematic of Figure 6 . A leaking hydraulic jack

Figure 6 - Scheme of the APULOT pull-out test method (19)

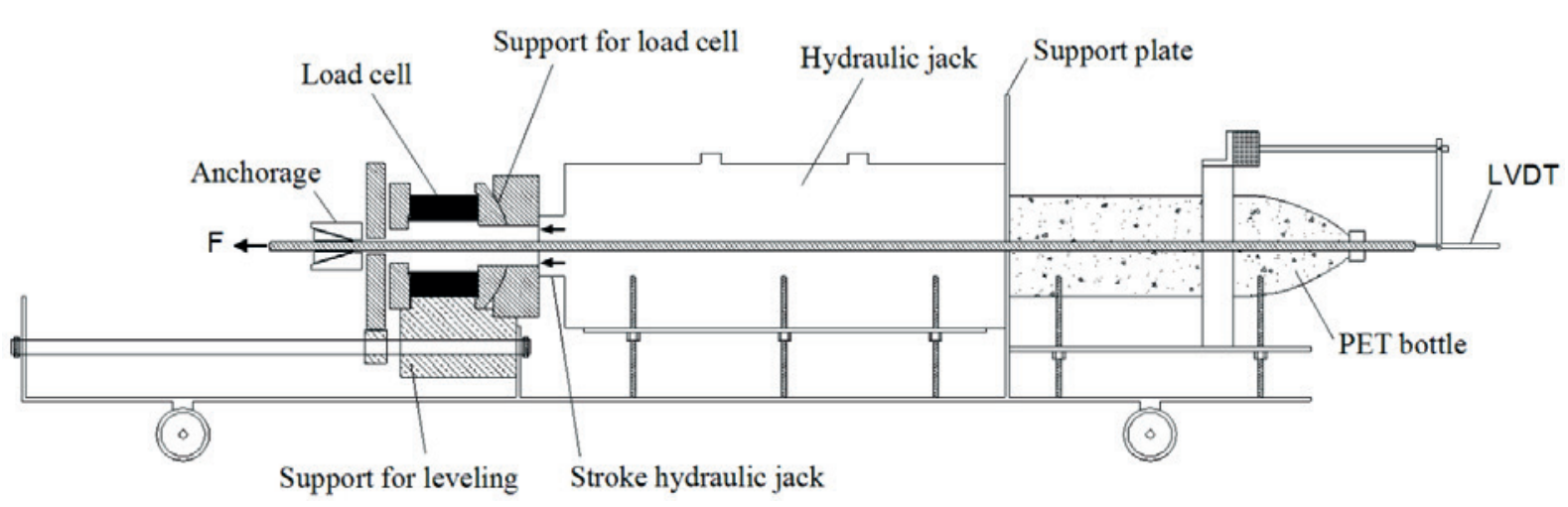




\section{Figure 7 - Type of rupture by slip of steel bar in the APULOT method with PET mold. (a) before and (b) after test}
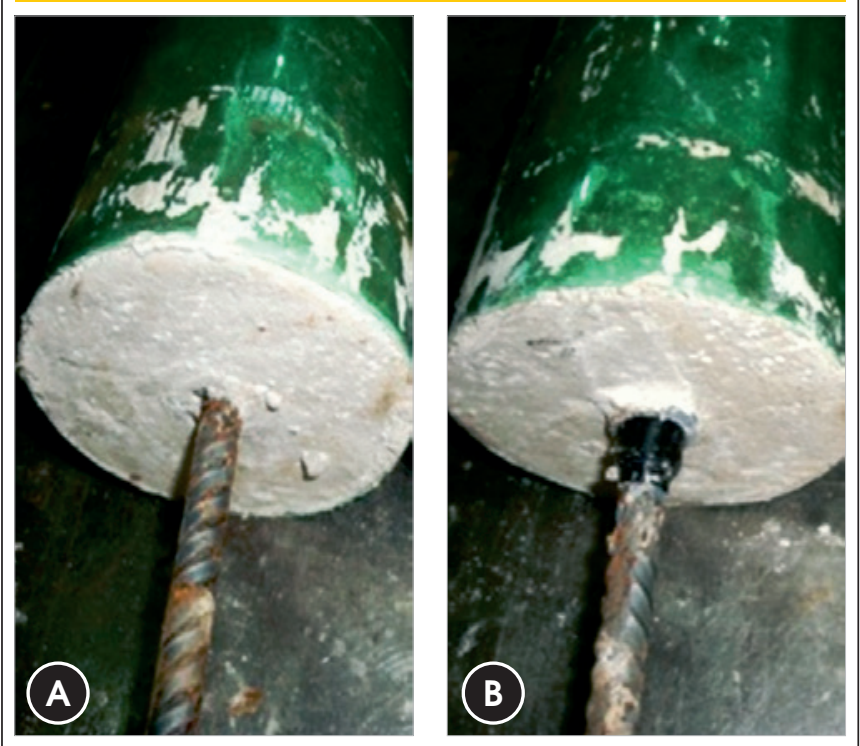

was used to apply the force with $600 \mathrm{kN}$ piston capacity, connected to a manual pressure pump where a traction force was applied at one end of the bar, which reacted against the test specimen.

The pull-out strength was measured by the load cell and linear displacement by LVDT (Linear Variable Differential Transformer) as illustrated in Figure 6. These data were transmitted to a "QuantumX" data acquisition system and viewed through the "CatmanEasy" software, both from HBM. This system enabled to obtain force curves versus displacement curves. The decision to use a load cell with a displacement transducer (LVDT) was to obtain additional test re- sults with respect to load increases with the relative steel and concrete slips and types of ruptures. The main goal of the method is to achieve the maximum force required to remove the bar from the concrete, which at a later field implementation stage, only one load cell can be used with a reading ability equivalent to the load of the hydraulic cylinder coupled to a digital or analog load display.

To study the APULOT steel-concrete bond, two concrete compositions (T25 and T45) three rupture ages ( 3 days, 7 days and 28 days) and three steel bar diameters CA-50 $(8 \mathrm{~mm}$ and $10 \mathrm{~mm}$ and 12.5 $\mathrm{mm}$ ) were tested. Eight test specimens were tested for each combination described above, totaling 144 tests. For all types of concreting performed, the compressive strength of the concrete was checked using cylindrical test specimens $(\varnothing 10 \times 20 \mathrm{~cm})$, whose results were presented in the previous article (Part 1)[4]. The tests performed enabled to obtain the intensities of the forces due to the steel bar slip. In accordance with the recommendations of CEB/FIP RC6:1983[3], with this force value divided by the lateral anchorage area of the bar, the bond stress $\left(\tau_{\mathrm{b}}\right)$ was calculated, as shown in Equation 2.

$$
\tau_{\mathrm{b}}=\frac{\mathrm{F}}{\pi \cdot \emptyset \cdot \mathrm{l}_{\mathrm{exp}}}
$$

Where $F$ is the pull-out force, $\varnothing$ is the diameter of the steel bar and $I_{\text {exp }}$ is the anchorage length of the test. It should be noted that the maximum bond stress $\left(\tau_{\text {bmax }}\right)$ was calculated based on the maximum pull-out strength.

\section{Results and discussions}

This section presents the results obtained in the APULOT tests, which analyzes the mechanical behavior of the steel bars pulled from the concrete through slip curves, according to the bond strength and the correlation between the maximum bond stress and the axial compressive strength of the concrete.

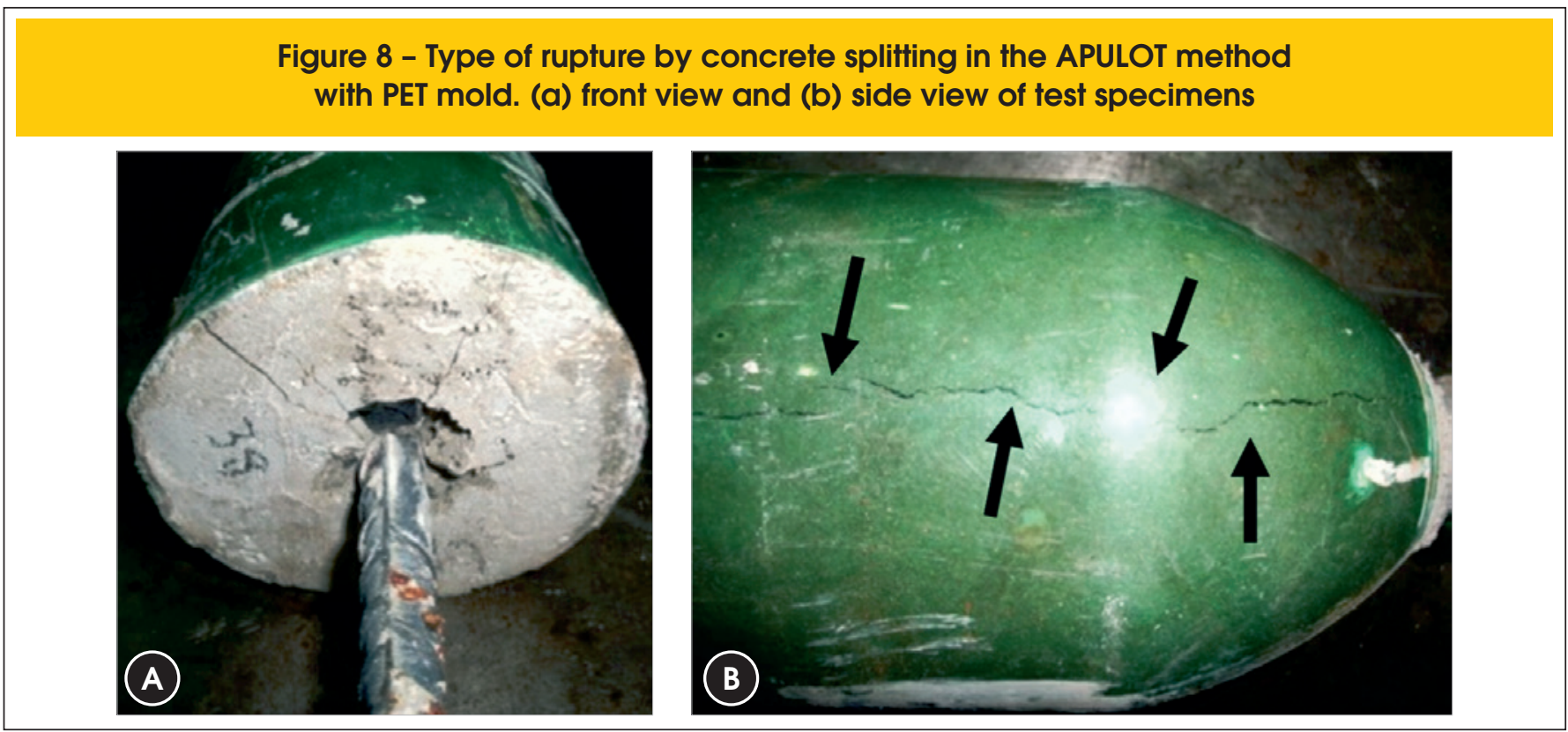




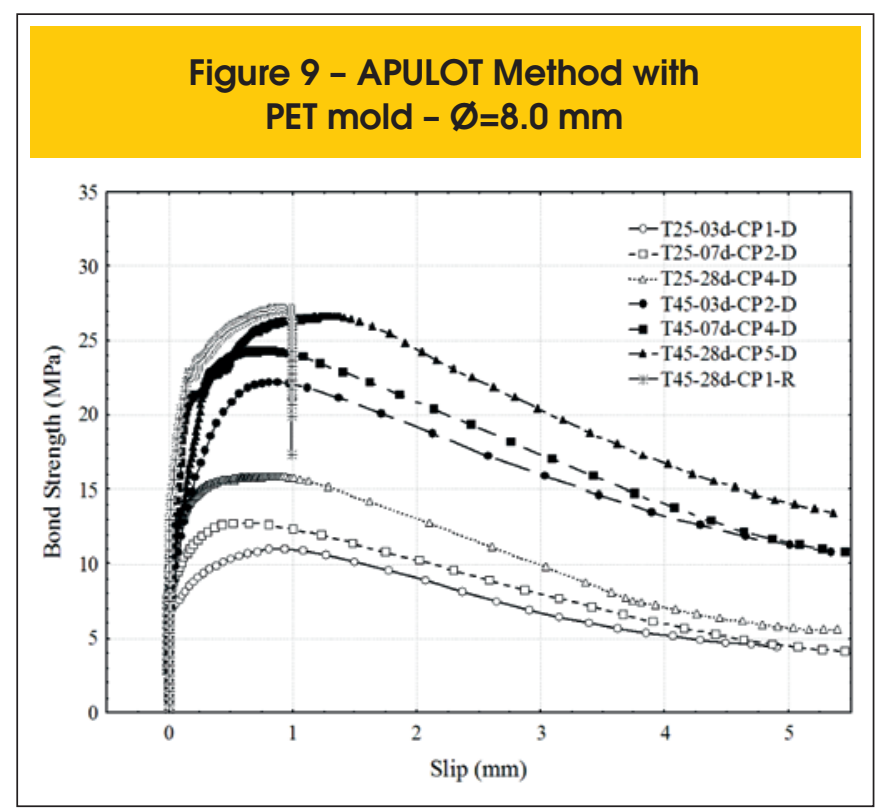

\subsection{Bond-stress curves vs. steel bar slip curves}

Through the slip curves vs. the bond stress, the mechanical behavior the test specimens' rupture was evaluated, verifying in which test specimens the steel bar slip occurred relative to the concrete, the concrete splitting or steel bar rupture. Different types of rupture were found: for the $8.0 \mathrm{~mm}$ diameter steel bars most of the specimens (96\%) showed steel bar slip relative to the concrete; the 10.0 $\mathrm{mm}$ bars had steel bar slip relative to the concrete $(75 \%)$; while in the $12.5 \mathrm{~mm}$ bars all specimens had concrete splitting rupture. Figures $7(\mathrm{a})$ and $7(\mathrm{~b})$ show the steel bar slip relative to the concrete before and after the APULOT test and Figures $8(\mathrm{a})$ and $8(\mathrm{~b})$ show the type of concrete splitting rupture in the APULOT test.

Figures 9, 10, 11 and 12 show the differences in the bond stress

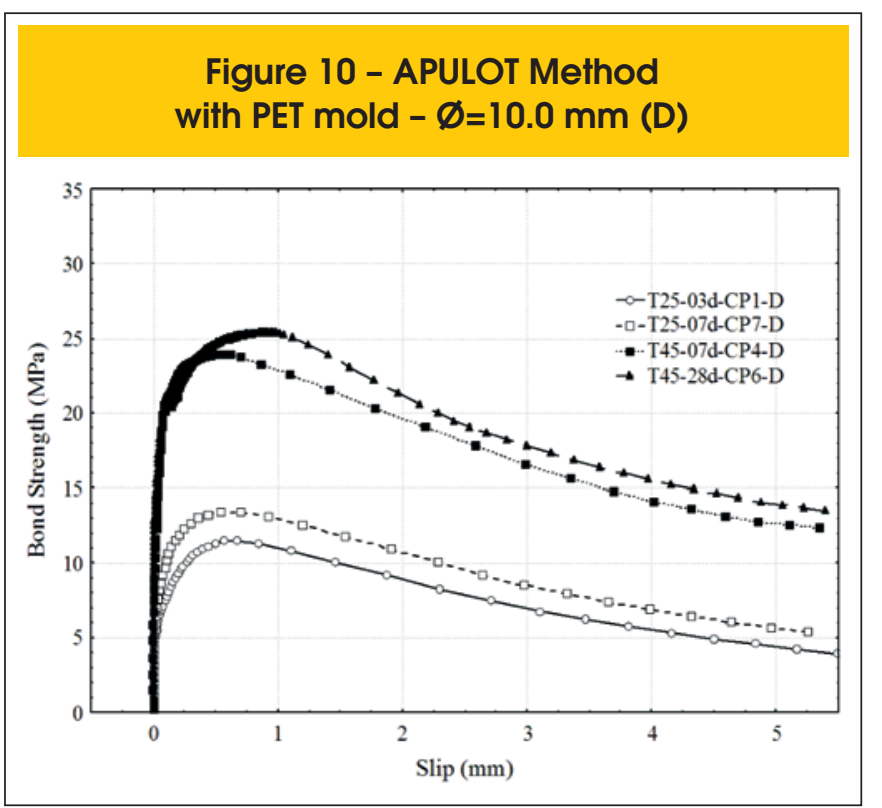

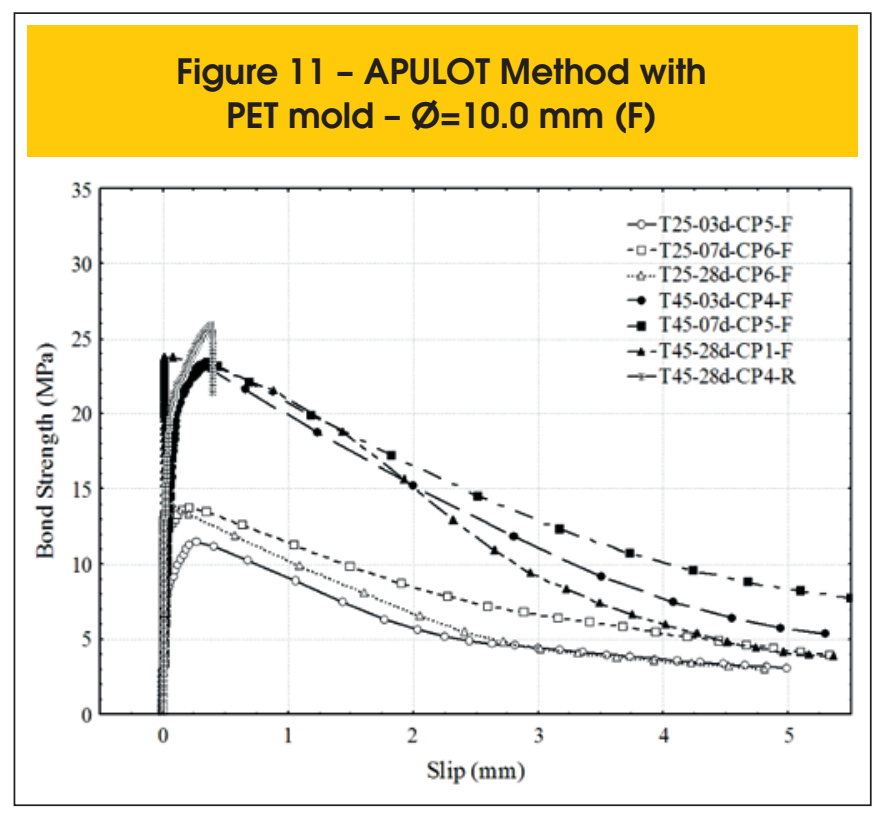

curves vs. slip curves for the APULOT method according to the concrete composition and age, using PET mold and $8 \mathrm{~mm}, 10 \mathrm{~mm}$ and $12.5 \mathrm{~mm}$ bars, respectively.

Figure 9 illustrates the curves obtained for the tests using $8.0 \mathrm{~mm}$ bars, which shows the steel bar slip in relation to the concrete at all ages for the T25 samples, and for the T45 specimens there was slip rupture at 3 and 7 days, and at 28 days, in addition to slip, there was yielding of the steel, and in the series there was steel rupture of one test specimen, as shown in Figure 9.

Figure 10 illustrates the curves obtained for the test using $10.0 \mathrm{~mm}$ bars which show the type of slip rupture of the steel bar relative to the concrete, for T25 and T45. Figure 11 illustrates the curves obtained for the tests using $10.0 \mathrm{~mm}$ bars, showing the type of rupture by splitting of the concrete, for T25 and T45, and also shows

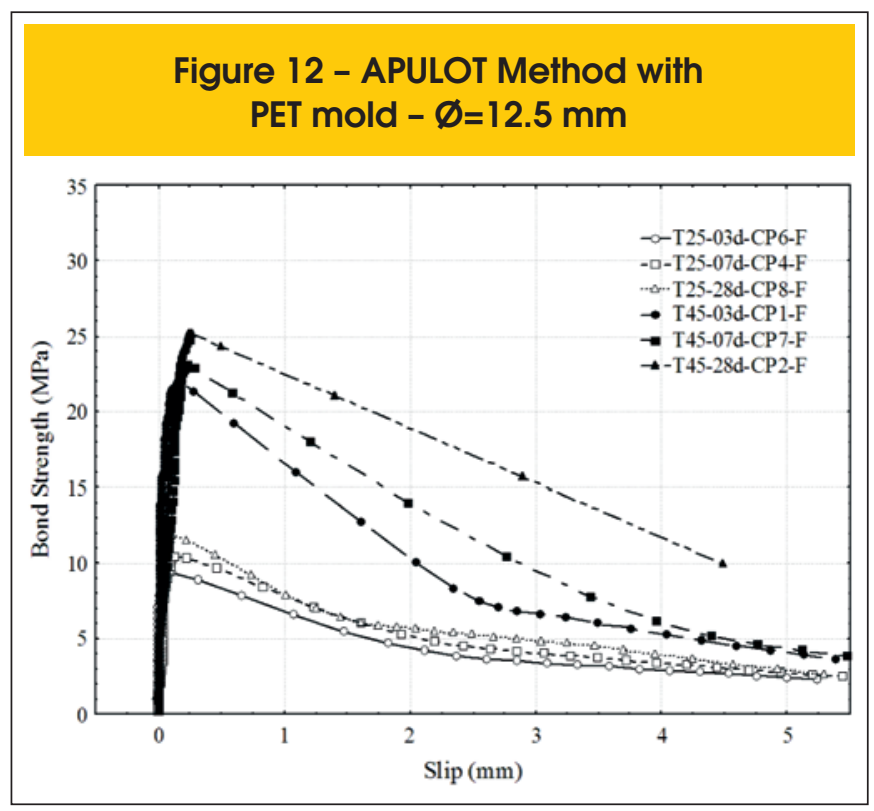


the steel rupture in one specimen of the series. Figure 12 illustrates the curves obtained for the tests using $12.5 \mathrm{~mm}$ bars, which show the type of rupture by splitting of the concrete in all tests. Table 1 shows the types of ruptures observed in the APULOT test specimens, where the letter " $D$ " means that there was slip of the steel bar relative to the concrete; the letter " $F$ " means that splitting occurred in the concrete specimen and the letter " $R$ " means that there was rupture of the steel bar.

It is observed that splitting occurred in $100 \%$ of the $12.5 \mathrm{~mm}$ bars, and in $23 \%$ of the $10.0 \mathrm{~mm}$ bars, and only in $4 \%$ of the $8.0 \mathrm{~mm}$ bars, hence showing a transition zone between the steel bar slip and concrete splitting for the relationship between $\operatorname{dec} / \varnothing>4.5$ and $c / \varnothing<5.75$, where $c / \varnothing$ is the relationship of the concrete cover around the steel bar. This fact is related to the PET bottle mold used, which did not have the suitable dimensions to withstand the stresses caused by the increasing diameter of the bars. These results are consistent with those obtained by Makini et al. (2010)[12], which showed that for the rupture by slip to occur the ratio should be $c / \varnothing \geq 5$. Other authors, such as Torre-Casanova et al. (2013) [20], showed that the $c / \varnothing>4.5$ ratio is required for the occurrence of rupture by slip of the steel bar.

\section{Table 1 - Types of ruptures observed in the APULOT test specimens}

\begin{tabular}{|c|c|c|c|c|c|}
\hline $\begin{array}{c}\text { Description } \\
\text { Composition - } \varnothing(\mathrm{mm})\end{array}$ & $(c / \varnothing)$ & $\begin{array}{l}\text { Age } \\
\text { (days) }\end{array}$ & D & $\mathbf{F}$ & $\mathbf{R}$ \\
\hline \multirow{3}{*}{ T25 - 8.0} & \multirow{3}{*}{5.75} & 3 & 7 & 1 & 0 \\
\hline & & 7 & 8 & 0 & 0 \\
\hline & & 28 & 8 & 0 & 0 \\
\hline \multirow{3}{*}{ T45 - 8.0} & \multirow{3}{*}{5.75} & 3 & 8 & 0 & 0 \\
\hline & & 7 & 8 & 0 & 0 \\
\hline & & 28 & 7 & 0 & 1 \\
\hline TOTAL & & & $96 \%$ & $2 \%$ & $2 \%$ \\
\hline $\begin{array}{c}\text { Description } \\
\text { Composition - } \emptyset(\mathrm{mm})\end{array}$ & $(c / \varnothing)$ & $\begin{array}{l}\text { Age } \\
\text { (days) }\end{array}$ & D & $\mathbf{F}$ & $\mathbf{R}$ \\
\hline \multirow{3}{*}{ T25 - 10.0} & \multirow{3}{*}{4.50} & 3 & 6 & 2 & 0 \\
\hline & & 7 & 7 & 1 & 0 \\
\hline & & 28 & 4 & 4 & 0 \\
\hline \multirow{3}{*}{ T45 - 10.0} & \multirow{3}{*}{4.50} & 3 & 7 & 1 & 0 \\
\hline & & 7 & 7 & 1 & 0 \\
\hline & & 28 & 5 & 2 & 1 \\
\hline TOTAL & & & $75 \%$ & $23 \%$ & $2 \%$ \\
\hline $\begin{array}{c}\text { Description } \\
\text { Composition - } \varnothing(\mathrm{mm})\end{array}$ & (c/ø) & $\begin{array}{l}\text { Age } \\
\text { (days) }\end{array}$ & D & $\mathbf{F}$ & $\mathbf{R}$ \\
\hline \multirow{3}{*}{ T25 - 12.5} & \multirow{3}{*}{3.50} & 3 & 0 & 0 & 8 \\
\hline & & 7 & 0 & 0 & 8 \\
\hline & & 28 & 0 & 0 & 8 \\
\hline \multirow{3}{*}{ T45 - 12.5} & \multirow{3}{*}{3.50} & 3 & 0 & 0 & 8 \\
\hline & & 7 & 0 & 0 & 8 \\
\hline & & 28 & 0 & 0 & 8 \\
\hline TOTAL & & & $0 \%$ & $0 \%$ & $100 \%$ \\
\hline
\end{tabular}

\section{Figure 13 - Example of type of rupture by slip and type of rupture by splitting}

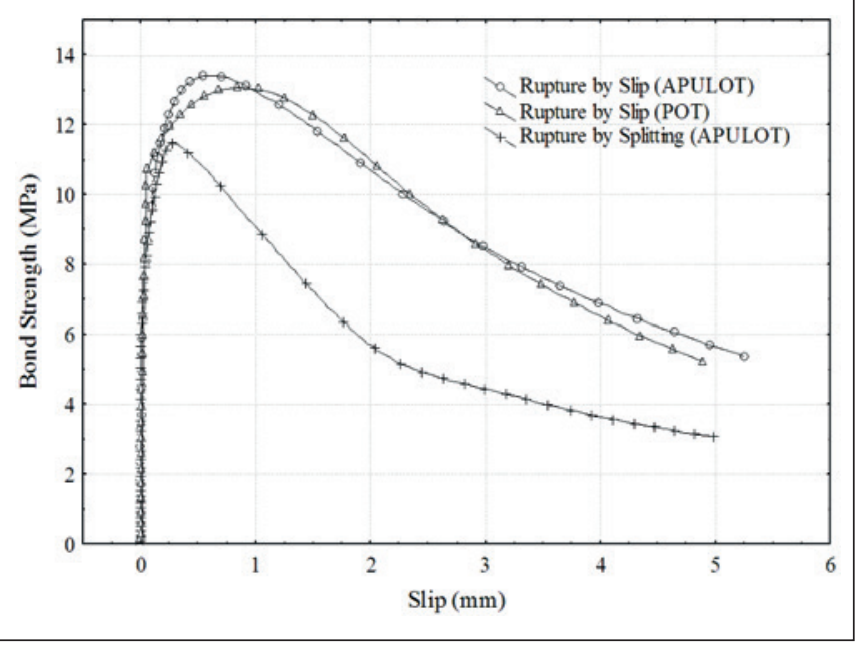

Figure 13 shows an example of the type of rupture by slip and the type of rupture by splitting, evidencing that in the POT or APULOT test the maximum bond stress is equivalent, provided that the proper containment conditions (c/ $\varnothing$ ratio) and the type of rupture by slip are maintained.

With the mechanical behavior of the test specimens analyzed through the slip curves according to the bond strength, the correlation between the maximum bond strength and the compressive strength of the concrete was studied. However, as shown in the flowchart of Figure 2, the APULOT method is not applicable to the test specimens that exhibited rupture by splitting of the concrete and/or rupture of the steel bar, thus these results are excluded from the correlation curve.

\subsection{Analysis of the correlation between the maximum bond strength ( $\left.\tau_{\text {bmax }}\right)$ and compressive strength $\left(f_{\partial}\right)$}

Table 2 and Figure 14 show the results obtained from the APULOT bond tests, as well as the composition and age of the concrete, the axial compression results and the diameter of the steel bar. Note that the correlation analysis between the variables $f_{c}$ and $\tau_{\text {bmax }}$ is valid only for the results where the steel bar slip of the concrete was found, so the results with $\varnothing=10 \mathrm{~mm}$ and $\varnothing=12.5 \mathrm{~mm}$ were compromised because in these results the splitting and rupture of the steel bar were observed in some cases.

In order to apply the APULOT method, keeping to the results where steel slip was observed on the concrete, the graph in Figure 15 shows the two compositions (T25 and T45) for the results using $\varnothing=8 \mathrm{~mm}$. Figure 15 shows the occurrence of non-linearity between the change in anchor length of $6 \varnothing$ to $10 \varnothing$, where this change in anchoring length generated two families of correlation curves between the variables $\tau_{\mathrm{bmax}} \times \mathrm{f}_{\mathrm{cm}}$, whereby the results clearly explain that there is a need to set this parameter in the test methodology, because there is a better correlation if the anchorage length is set. In order to correlate the compressive strength of concrete with the maximum steel-concrete bond strength, linear regressions were per- 


\section{Table 2 - Maximum bond stress values achieved in the APULOT tests and} axial compressive strength values together with the standard deviation

\begin{tabular}{|c|c|c|c|c|c|}
\hline \multirow{2}{*}{$\begin{array}{l}\text { Concrete } \\
\text { composition }\end{array}$} & \multirow{2}{*}{$\begin{array}{l}\text { Age } \\
\text { (days) }\end{array}$} & \multirow{2}{*}{$\begin{array}{c}f_{c m} \\
(M P a)\end{array}$} & $\varnothing=8 \mathrm{~mm}$ & $\varnothing=10 \mathrm{~mm}$ & $\varnothing=12.5 \mathrm{~mm}$ \\
\hline & & & $\tau_{\text {bmax }}(\mathrm{MPa})$ & $\tau_{\text {bmax }}(\mathbf{M P a})$ & $\tau_{\text {bmax }}(\mathrm{MPa})$ \\
\hline T25 & 3 & $16.7 \pm 1.1$ & $11.16 \pm 0.92$ & $11.66 \pm 0.53$ & $9.25 \pm 0.25$ \\
\hline T25 & 7 & $21.1 \pm 1.6$ & $13.34 \pm 1.00$ & $13.27 \pm 0.37$ & $10.53 \pm 0.34$ \\
\hline T25 & 28 & $28.0 \pm 1.8$ & $15.55 \pm 0.76$ & $14.43 \pm 0.47$ & $11.94 \pm 0.95$ \\
\hline T45 & 3 & $33.1 \pm 1.5$ & $22.73 \pm 1.66$ & $23.02 \pm 0.90$ & $21.69 \pm 1.09$ \\
\hline T45 & 7 & $40.5 \pm 1.7$ & $24.48 \pm 0.83$ & $23.98 \pm 0.77$ & $23.11 \pm 0.78$ \\
\hline T45 & 28 & $49.9 \pm 1.8$ & $26.06 \pm 1.16$ & $25.65 \pm 1.12$ & $24.91 \pm 1.41$ \\
\hline
\end{tabular}

formed between the compressive strength and bond values. As previously explained, a specific linear regression was carried out for each anchorage length. Table 3 shows the regressions and the values of the determination coefficients obtained for the $8.0 \mathrm{~mm}$ bars. It can be seen that the coefficients of determination $\left(R^{2}\right)$ achieved satisfactory values, that is, values close to value 1 . Similarly, it was found that all angular coefficients are always positive, that is, in the strength range tested there was a significant behavior tendency which was characterized by an increase in the maximum bond strength proportional to the increasing axial compression strength of the concrete.

\subsection{Standardization of the APULOT methodology}

Most methods used in the quality control of reinforced concrete have predefined methodologies based on specific standardizations. The objective of these standardized methodologies is to standardize the tests, in other words, to improve the reproducibility and accuracy of their responses, reducing the usual errors and uncertainties underlying in the procedure. It can be said that the APULOT methodology is still in the experimental stage, therefore it is crucial to test the parameters that influence the test response for

Figure 14 - General maximum bond stress values achieved in the APULOT tests

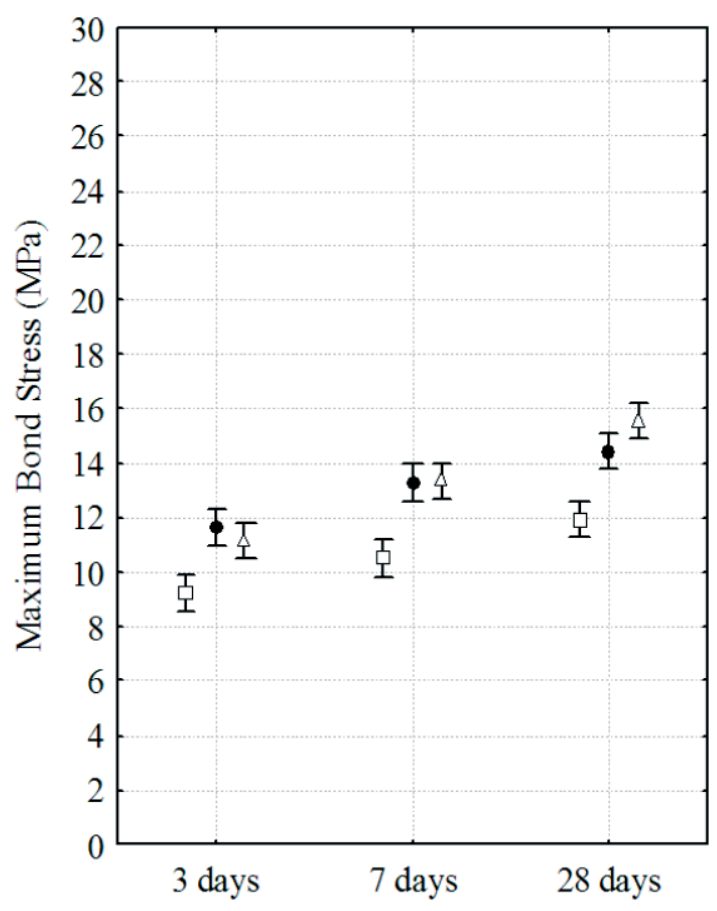

Anchorage Length: $10 \varnothing$ Composition: T25

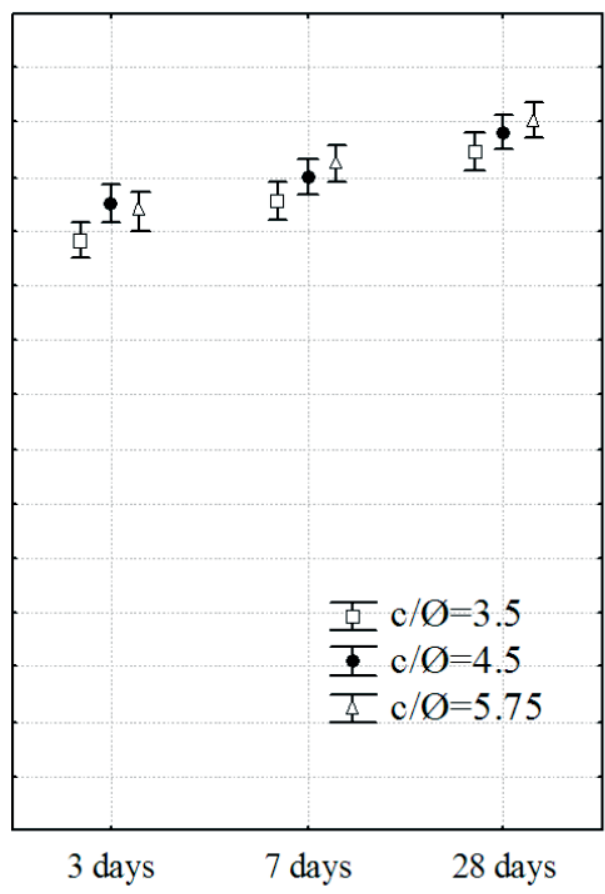

Anchorage Length: $6 \varnothing$ Composition: T45 


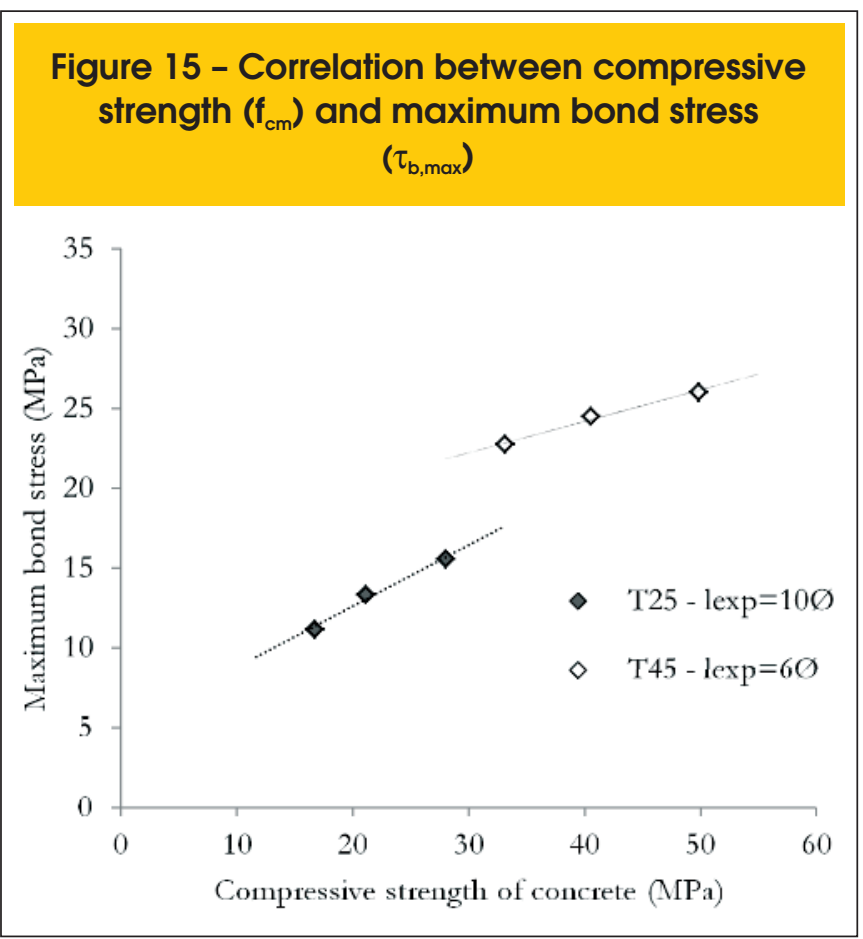

the correct development of the method. Thus, it is known that the preparation procedures of the mold, preparation of steel bar, concrete density in the mold, unmolding procedures, and the storage and curing of test specimens before the test date are essential for the correct response of the method. Given these points, parameters were set for the APULOT test as a measure of standardization and comparison for future tests, as shown in Table 4.

As can be seen in Table 4, the APULOT method requires the definition of certain parameters, and results with different models cannot be compared. In other words, setting parameters is critical for the proper performance of the APULOT methodology in order to estimate the compressive strength.

\section{Conclusions}

The correlation curves obtained in this study substantiate the method proposed by Lorrain and Barbosa (2011)[1] and [2], which is to transform the bonding tests into qualification tests of reinforced concrete due to the good proportionality of the axial compressive strength and maximum bond stress. The correlation analysis between the maximum bond strength and compressive strength for the APULOT test with $\varnothing=8 \mathrm{~mm}$ allows to conclude that the bond tests are suitable for estimating the axial compressive strength of the concrete, provided they comply with the parameters listed in Table 4, particularly the relationship between the concrete cover around the bar and the bar diameter (c/Ø), which must be greater than 5 for the occurrence of rupture by slip.

The application of the APULOT method with $10.0 \mathrm{~mm}$ and $12.5 \mathrm{~mm}$ bar diameters requires increasing the concrete cover around the bars, ensuring the rupture by slip. In other words, increasing the diameter of the molds is indispensable in order to implement the methodology, as illustrated in Figure 2.

The response of the method for concrete tested at 7 days makes it specifically interesting when decision making support is needed regarding nonconforming concrete at early ages. The standardization of the method presented in Table 4 is vital for its proper implementation and for comparing the results of subsequent research endeavors.

Finally, it is believed that demystifying the bond test will be of a great assistance to the quality control of concrete works, enabling to increase the control at construction sites and at lower costs. However, to standardize the method to safely implement it at construction sites requires numerous tests and repetitions in order to verify the limitations and ranges regarding the different types of materials used in different locations.

\section{Acknowledgements}

We are grateful to FAPESP (Fundação de Amparo à Pesquisa do Estado de São Paulo); To CNPQ (Conselho Nacional de Desenvolvimento Científico e Tecnológico); To LCEC (Laboratório CESP de Engenharia Civil - Ilha Solteira/SP); To the Central Civil Engeneering Laboratory of UNESP - Ilha Solteira/SP; To the company ArcelorMittal that provided the steel bars; To the company Holcim do Brasil for providing the cement; and to the company Grace Concrete Products for supplying the superplasticizer.

\section{References}

[01] LORRAIN, M. S.; BARBOSA P. M. Controle de qualidade dos concretos estruturais: ensaio de aderência aço-concreto. In: Revista Concreto\& Construções, São Paulo, N51, $3^{\circ}$ trimestre, p. 52-57, 2008.

[02] LORRAIN, M. S. ; BARBOSA, M. P. ; SILVA FILHO, L. C. P. Estimation of compressive strength based on Pull-Out bond test results for on-site concrete quality control. Revista IBRACON de Estruturas e Materiais, v. 4, p. 4, 2011.

[03] COMITÉ EURO-INTERNATIONAL DU BÉTON. RILEM/ CEB/FIP RC6: Bond test for reinforcement steel - 2 Pull-out test. Paris, 1983.

Table 3 - Equations of linear regression lines and their respective determination coefficients

\begin{tabular}{cccccc}
$\begin{array}{c}\text { Diameter } \\
(\mathrm{mm})\end{array}$ & $\begin{array}{c}\text { Concrete } \\
\text { composition }\end{array}$ & $\begin{array}{c}\text { Range compressive } \\
\text { strength }(\mathrm{MPa})\end{array}$ & $\begin{array}{c}\text { Anchorage } \\
\text { length }\end{array}$ & $\begin{array}{c}\text { Linear } \\
\text { regression }\end{array}$ & $\begin{array}{c}\text { Coefficient of } \\
\text { determination }\end{array}$ \\
\hline 8 & $\mathrm{~T} 25$ & 16.7 to 28.0 & $10 \varnothing$ & $\tau_{\text {bmax }}=0.38 \mathrm{f}_{\mathrm{cm}}+4.9$ & $\mathrm{R}^{2}=0.98$ \\
8 & $\mathrm{~T} 45$ & 33.1 to 49.9 & $6 \varnothing$ & $\tau_{\mathrm{bmax}}=0.20 \mathrm{f}_{\mathrm{cm}}+16.3$ & $\mathrm{R}^{2}=0.97$ \\
\hline
\end{tabular}




\section{Table 4 - Parameters for the standardization of the test method in the field}

\begin{tabular}{|c|c|c|c|c|}
\hline \multicolumn{3}{|c|}{ Method parameters } & Possibilities & Model 1 (APULOT) \\
\hline \multirow{2}{*}{ Mold } & 1 & $\begin{array}{c}\text { Material of the mold for the } \\
\text { test specimen }\end{array}$ & $\begin{array}{l}\text { (a) Metal, (b) nylon fiber, } \\
\text { (c) wood or (d) PET }\end{array}$ & (d) PET \\
\hline & 2 & $\begin{array}{c}\text { Format of the mold for the } \\
\text { test specimen }\end{array}$ & $\begin{array}{l}\text { (a) Cylindrical, (b) cubic } \\
\text { or (c) prismatic }\end{array}$ & (a) Cylindrical \\
\hline \multirow{5}{*}{$\begin{array}{l}\text { Preparation } \\
\text { and molding } \\
\text { of tests }\end{array}$} & 3 & Anchorage length (le) & $3 \varnothing \leq 1 e \leq 10 \varnothing$ & $5 \varnothing$ \\
\hline & 4 & $\begin{array}{l}\text { Ratio of concrete cover } \\
\text { around the steel bar }(c / \varnothing)\end{array}$ & $c / \varnothing>5$ & 5.75 \\
\hline & 5 & $\begin{array}{l}\text { Layout of the bar at } \\
\text { concreting time }\end{array}$ & $\begin{array}{l}\text { (a) Horizontal or } \\
\text { (b) Vertical }\end{array}$ & (b) Vertical \\
\hline & 6 & $\begin{array}{l}\text { Concrete density } \\
\text { in the mold }\end{array}$ & $\begin{array}{l}\text { (a) Mechanic with } \\
\text { vibrating table or (b) } \\
\text { Manual with metal rod }\end{array}$ & (b) Manual with metal rod. \\
\hline & 7 & Number of test specimens & $\begin{array}{c}\geq 2 \text { test specimens } \\
\text { per example }\end{array}$ & - \\
\hline \multirow{3}{*}{ Steel Bars } & 8 & $\begin{array}{c}\text { Type of geometrical } \\
\text { configuration of the CA- } 50 \\
\text { ribbed bars }\end{array}$ & Type 1, 2, 3 ... etc. & $\begin{array}{c}\text { Type } 1 \\
\text { (illustrated in part } 1 \\
\text { of this paper (4)) }\end{array}$ \\
\hline & 9 & $\begin{array}{c}\text { Diameter of the CA-50 } \\
\text { steel bar }\end{array}$ & $\begin{array}{c}\text { (a) } \varnothing=8 \mathrm{~mm} ; \\
\text { (b) } \varnothing=10 \mathrm{~mm} ; \\
\text { (c) } \varnothing=12.5 \mathrm{~mm} \ldots \text {...tc. }\end{array}$ & (a) $8 \mathrm{~mm}$ \\
\hline & 10 & State of the bar surface & $\begin{array}{l}\text { (a) No surface oxidation or } \\
\text { (b) with surface oxidation }\end{array}$ & (a) No surface oxidation \\
\hline \multirow[t]{2}{*}{ Concrete } & 11 & $\begin{array}{l}\text { Compressive strength } \\
\text { of concrete }\end{array}$ & $\begin{array}{l}\text { Group 1: fc } \leq 50 \mathrm{Mpa} \\
\text { Group 2: } 50<\mathrm{fc} \leq 100 \mathrm{Mpa} \\
\text { ABNT NBR } 8953: 2011\end{array}$ & $\begin{array}{l}\text { Group 1: C15; C20; C25; } \\
\text { C30; C35; C40; C45; C50. } \\
\text { Group 2: C55; C60; C70. }\end{array}$ \\
\hline & 12 & $\begin{array}{l}\text { Characteristic maximum } \\
\text { dimension of the aggregates }\end{array}$ & $\begin{array}{l}4 x \text { smaller than the } \\
\text { minimum size of the mold }\end{array}$ & $\mathrm{D}_{\max } \leq 25 \mathrm{~mm}$ \\
\hline \multirow[b]{2}{*}{$\begin{array}{l}\text { Demolding, } \\
\text { Curing and } \\
\text { Storage }\end{array}$} & 13 & Demolding time & $\geq 24 h$ & $24 \mathrm{~h}$ \\
\hline & 14 & $\begin{array}{l}\text { Curing and storage } \\
\text { of test specimens }\end{array}$ & $\begin{array}{l}\text { (a) Only stored away from } \\
\text { weather conditions; (b) } \\
\text { Humid chamber with } \\
\text { temperature of } 23 \pm 2^{\circ} \mathrm{C} \\
\text { and relative air humidity } \\
\text { higher than } 95 \% \text {; (c) } \\
\text { Saturated solution of } \\
\text { calcium hydroxide } \\
\text { with temperature of } \\
23 \pm 2^{\circ} \mathrm{C}\end{array}$ & $\begin{array}{l}\text { (c) saturated solution } \\
\text { of calcium hydroxide } \\
\text { with temperature } \\
\text { of } 23 \pm 2^{\circ} \mathrm{C}\end{array}$ \\
\hline \multirow{4}{*}{$\begin{array}{l}\text { Execution } \\
\text { of tests }\end{array}$} & 15 & Rupture age & $\geq 3$ days & 7 days \\
\hline & 16 & Type of loading & (a) Pull-out or (b) Push-in & (a) Pull-out \\
\hline & 17 & Loading rate & Controlled speed or not & $\begin{array}{c}\text { Manually controlled speed. } \\
\text { Test duration not } \\
\text { less than 60s }\end{array}$ \\
\hline & 18 & Type of rupture & $\begin{array}{l}\text { (a) Slip; (b) Concrete } \\
\text { splitting; (c) Rupture of bar }\end{array}$ & (a) Slip \\
\hline
\end{tabular}


[04] VALE SILVA, B.;BARBOSA, M.P.; SILVA FILHO, L. C. P.; LORRAIN, M.S.. Experimental investigation on the use of steel-concrete bond tests for estimating axial compressive strength of concrete: part 1. Revista IBRACON de Estruturas e Materiais, v. 6, p. 715-736, 2013.

[05] ALVAREZ, M.: Einfluss des Verbundverhaltens auf das Verformungsvermögen von Stahlbeton. ETH Zürich, Diss., Basel: Birkhäuser (IBK Bericht 236), 1998.

[6] AMERICAN CONCRETE INSTITUTE. ACI 408R: Bond and development of straight reinforcing bars in tension. Farmington Hills, 2003.

[07] BARBOSA, M.P. ; GASPARETO, K. ; VALE SILVA, B. ; SILVA FILHO, L. C. P. ; LORRAIN, M. . Experiências sobre a influência da corrosão superficial das armaduras nos ensaios de aderência APULOT. In: CONPAT 2011 - Congreso Latino americano de Patología de la Construcción y el Congreso de Control de Calidadenla Construcción, 2011, ANTIGUAGUATEMALA. ANAIS DO CONPAT 2011. GUATEMALA, p. 17-24.2011.

[08] DAL BOSCO, V. I. ; VALE SILVA, B. ; TROIAN, P. ; BARBOSA, M.P. ; SILVA FILHO, L. C. P. Comparativo experimental entre os métodos de ensaios pull-out e push-out para determinação da tensão de aderência aço-concreto. In: $54^{\circ}$ Congresso Brasileiro do Concreto, 2012, Maceió/AL. Anais do 54 CBC. São Paulo/SP: IBRACON, 2012.

[09] LORRAIN, M. ; CAETANO, L. F. ; VALE SILVA, B. ; GOMES, L.E.S. ; BARBOSA, M. P. ; SILVA FILHO, L. C. P. . Bond strength and rib geometry: a comparative study of the influence of deformation patterns on anchorage bond strength. In: PCI Annual Convention \& 3rd International FIB Congress FIB, WASHINGTON, D C. CHIGACO: 3rd FIB International Congress FIB, 2010.

[10] SILVA FILHO, L. C. P. ; VALE SILVA, B. ; DAL BOSCO, V. I. ; GOMES, L.E.S. ; BARBOSA, M.P. ; LORRAIN, M. Analysis of the influence of rebar geometry variations on bonding strength in the pull-out test. In: Bond in Concrete 2012 - Bond, Anchorage, Detailing, 2012, Brescia, Italy. General aspects of bond, Vol. 1. 2012.

[11] VALE SILVA, B. ; BARBOSA, M.P. ; SILVA FILHO, L. C. P. ; LORRAIN, M. ; DAL BOSCO, V. I. Correlação entre a tensão última de aderência e a resistência do concreto usando ensaio APULOT : avaliação do efeito de variação do cobrimento do concreto ao redor da barra de aço. In: $53^{\circ}$ Congresso Brasileiro do Concreto, 2011, Florianópolis/SC. Anais do $53^{\circ}$ CBC. São Paulo/SP: IBRACON, 2011.

[12] MAKNI, M.; DAOUD, A.; KARRAY, M. A.; LORRAIN, M.. Towards a standard pull-out test specimen: geometrical specifications. 3rd fib International Congress. Washington D. C., FIB, 2010.

[13] VALE SILVA, B. ; LORENZI, A. ; BARBOSA, M.P. ; SILVA FILHO, L. C. P. Análise dos resultados de ensaios de aderência aço-concreto através da utilização de redes neurais artificiais. In: $55^{\circ}$ Congresso Brasileiro do Concreto, 2013, Gramado/ RS. Anais do $55^{\circ} \mathrm{CBC}$. São Paulo/SP: IBRACON, 2013.

[14] BARBOSA, M. P. ; PEREIRA, J.B.;LORRAIN, M.; Análise experimental e avaliação da influência da resistência àcompressão do concreto no ensaio de aderência APULOT. In: $55^{\circ}$ Congresso Brasileiro do Concreto, 2013, Gramado/RS. Anais do $55^{\circ} \mathrm{CBC}$. São Paulo/SP: IBRACON, 2013.
[15] GARCÍA-TAENGUA E.; MARTÍ-VARGAS J. R.; SERNAROS P.. Bond of reinforcement in concrete applied to concrete quality control: The Bottle Bond Test. Strain, v.50, p.57-67, 2014

[16] CALDERARO, R. P.; BARBOSA, M.P. Aderência Aço-Concreto: Análise experimental da influência da variação da geometria da garrafa PET e do cobrimento do concreto ao redor da barra de aço. In: $54^{\circ}$ Congresso Brasileiro do Concreto, 2012, Maceió/AI, Anais do $54^{\circ} \mathrm{CBC}$. São Paulo/SP: IBRACON, 2013.

[17] TAVARES, A. J. Aderência aço-concreto: Análise numérica dos ensaios pull-out e APULOT. 2012. 141 f. Dissertação (Mestrado em Engenharia) - Faculdade de Engenharia da Universida de Estadual Paulista (UNESP), Ilha Solteira, 2012.

[18] TAVARES, A. J.; BARBOSA, M. P.; BITTENCOURT T. N.; LORRAIN, M.. Bond steel-concrete: simulation analysis of the pull-out tests and APULOT using the program ATENA. Revista IBRACON de Estruturas e Materiais, v. 7, p. 138157, 2014.

[19] VALE SILVA, B. Investigação do potencial dos ensaios APULOT e pull-out para estimativa da resistência a compressão do concreto. 2010. 178 f. Dissertação (Mestrado em Engenharia) - Faculdade de Engenharia da Universidade Estadual Paulista (UNESP), Ilha Solteira, 2010.

[20] TORRE-CASANOVA A.; JASON L.; DAVENNE L.; PINELLI $X$.. Confinement effects on the steel-concrete bond strength and pull-out failure. Engineering Fracture Mechanics, v.97, p 92-104, 2013.

\section{Nomenclature}

APULOT - Appropriate PULL-Out Test;

$\mathrm{F}$ - Force applied to the pull-out $(\mathrm{kN})$;

$\mathrm{I}_{\exp }$ - Experimental anchorage length $(\mathrm{mm})$;

Øৈ- Diameter of the steel bar $(\mathrm{mm})$;

POT - Pull-Out Test (RILEM/CEB/FIP RC6: 1983 [4]);

$\mathrm{f}_{\mathrm{c}}$ - Axial compressive strength (MPa);

$\mathrm{f}_{\mathrm{cm}}$ - Mean axial compressive strength (MPa);

$\mathrm{f}_{\mathrm{sy}}$ - Steel yield strength (MPa);

$\tau_{\mathrm{b}}$ - Bond strength between the steel and the concrete (MPa);

$\tau_{\mathrm{b}, \max }-$ Maximum bond stress between the steel and the concrete (MPa). 